\title{
Ontogenetic changes in the diet of juvenile brown tiger prawns Penaeus esculentus
}

\author{
C. J. O'Brien* \\ Centre for Marine Science, University of New South Wales, Sydney, Australia
}

\begin{abstract}
The diets of small (2 to $5 \mathrm{~mm}$ carapace length, $\mathrm{CL}$ ), medium (9 to $12 \mathrm{~mm} \mathrm{CL}$ ) and large (15 to $18 \mathrm{~mm} \mathrm{CL}$ ) Penaeus esculentus were determined for prawns collected from the same seagrass bed. The most common food types included copepods, decapods, ostracods, gastropods, diatoms, filamentous algae and seagrass. The diversity of food types increased with prawn size and included pronounced changes in the use of plant material. Plants are essential for the health of $P$. esculentus juveniles and they appeared to change their diet progressively from diatoms to filamentous algae to seagrass as they grew. $P$. esculentus juveniles are found, almost exclusively, on seagrass beds; feeding on seagrass and its epiphytes provides further evidence of the dependence of $P$ esculentus on their preferred habitat.
\end{abstract}

KEY WORDS: Diet - Ontogeny · Penaeid · Prawn - Seagrass

The types of animals eaten by penaeid prawns worldwide are similar and include crustaceans, molluscs, polychaetes and foraminiferans (Dall et al. 1990). Filamentous algae and diatoms appear to be the most common plants eaten by prawns (Dall et al. 1990). Seagrass material is apparently less common (e.g. Mohanty 1975, Wassenberg 1990). The use of both animals and plants by penaeid prawns changes with ontogeny (Wassenberg \& Hill 1987, Stoner \& Zimmerman 1988). This is probably related to increasing predatory ability with size e.g. an increase in the size and power of the chelae and mouthparts, and changing nutritional requirements (O'Brien 1992).

Juvenile brown tiger prawns Penaeus esculentus (Haswell) live, almost exclusively, in shallow water seagrass beds around the coasts of tropical and subtropical Australia (Dall et al. 1990). Seagrasses are important because they provide protection (Laprise \& Blaber 1992) and their associated biota is food (Was-

- Present address: CSIRO Division of Fisheries, Box 120 , Cleveland, Queensland 4163, Australia senberg \& Hill 1987, Wassenberg 1990). Although the diet of large $P$. esculentus juveniles has been examined to some extent by Wassenberg \& Hill (1987) and Wassenberg (1990) there is no information on prawns of $<8 \mathrm{~mm}$ carapace length (CL). In south Queensland, $P$. esculentus juveniles stay on the seagrass beds for longer than they do in other areas (O'Brien 1992) so there is likely to be a wide size range of conspecifics feeding on a common range of food types; this provides an ideal opportunity to examine ontogenetic changes in the diet.

In this study I examined the diet of 2 to $18 \mathrm{~mm} \mathrm{CL}$ Penaeus esculentus juveniles from one seagrass bed; as laboratory studies have shown that $P$. esculentus juveniles need plant material to survive (O'Brien 1992) special attention was paid to the types and quantities of plant material eaten.

Methods. Collection of prawns: Penaeus esculentus juveniles, 2 to $18 \mathrm{~mm}$ carapace length (CL), were collected with a $1 \times 0.5 \mathrm{~m}$ beam trawl fitted with a $2 \mathrm{~mm}$ mesh net from seagrass (Zostera capricorni Aschers.) of Toondah Harbour, south Queensland, Australia (27 $31^{\prime} \mathrm{S}, 153^{\circ} 17^{\prime}$ E) between 14 and 28 February 1991 when prawn densities were high (O'Brien 1992). Collections were made on the rising tide at night and during the day to examine diel changes in diet. Trawl time was about $5 \mathrm{~min}$; captured prawns were immediately snap frozen $\left(-10^{\circ} \mathrm{C}\right)$ in an ice slurry consisting of seawater, rock salt and shave ice; onshore, they were stored at $-50^{\circ} \mathrm{C}$.

Laboratory procedure: Prawns were grouped into 3 size classes: 2 to 5 (small), 9 to 12 (medium), and 15 to $18 \mathrm{~mm}$ CL (large). Forty prawns from each size class were examined ( 20 each from the day and night collections). Prawns with empty foreguts were discarded from the study. Whole small prawns were placed into $70 \%$ ethanol for several days prior to dissection to 
firm-up the foregut wall and make the excision of the foregut easier. The foregut material was examined in one of several sizes of cavity slide: $5,10,12.5,15$ or $20 \mathrm{~mm}^{2}$, depending on the quantity. Each slide was etched with a $2.5 \mathrm{~mm}^{2}$ grid pattern. The depth of each cavity was the thickness of 1 coverslip (about $0.1 \mathrm{~mm}$ ); coverslips were glued to the slides using 'Loctite ${ }^{\otimes}$ Crystal Clear Glass Adhesive'.

Food items were identified to the lowest taxa possible. All of the procedures used for identifying the different food types eaten by each prawn were carried out on the same glass slide. Foregut contents were examined in the following way:

Animals: The foregut contents were stained with a dilute Rose Bengal solution. Animals were identified using a binocular microscope $(6 \times$ to $50 \times)$ fitted with a green filter, and a compound microscope $(100 \times$ to $200 \times)$.

Filamentous algae: The foregut contents were restained with Lugol's solution to highlight plant material (Throndson 1981) and filamentous algae were identified using the compound microscope. Following method 5 of Olson (1950), an estimate of the aggregate length of filamentous algae in each $2.5 \mathrm{~mm}^{2}$ grid on the glass slide was made using the dissecting microscope $(84 \times)$ fitted with a $20 \times 20$ line ocular grid i.e. each line on the ocular grid was $2.5 \mathrm{~mm} / 20=0.125 \mathrm{~mm}$ apart. The total length of algal filaments (all species combined) in each $2.5 \mathrm{~mm}^{2}$ equalled the sum of the number of intersections made by the algal filaments on both the horizontal and vertical lines of the ocular grid multiplied by $\left(\frac{\pi}{4} \times 0.125\right)$. The algal filaments in all the $2.5 \mathrm{~mm}^{2}$ squares within each cavity were counted and the sum of the lengths of filaments in each square gave a total estimate of the length of filamentous algae in the foregut of each prawn.

Diatoms: The diatoms in each foregut were exposed by adding droplets of concentrated nitric acid and hydrogen peroxide $\left(6 \% \mathrm{H}_{2} \mathrm{O}_{2}\right)$ to the foregut contents and warming the cavity slide on a hot-plate. When the organic material had been dissolved (after 24 to $48 \mathrm{~h}$ ) the acidic fluid in the cavity was diluted by adding droplets of distilled water and then evaporating them off by warming the cavity slide on the hot-plate. This 'rinsing' was done several times. On the final rinse a droplet of concentrated methylene blue solution was added to highlight the diatoms. After this solution had evaporated and the cavity slide had dried, a thin layer of immersion oil was added. Fields of view $(0.44 \mathrm{~mm}$ diameter) were selected in a systematic sweep of the cavity using the compound microscope $(400 \times)$, fitted with a blue filter. Because many of the taxonomic structures on the diatoms were not visible using the compound microscope, most diatoms were classified to genus using Thomas (1978), Ricard (1987) and Round et al. (1992). The proportional composition of the types of diatoms in each foregut was determined by counting the first 100 diatoms encountered. All recognisable fragments which were $>\frac{1}{4}$ their estimated complete size were counted. The number of fields of view required to count 100 diatoms was recorded so estimates of the total number of diatoms could be made. Where low numbers of diatoms were present, a maximum of 50 fields of view were counted.

Data analysis: Following the methods of Wassenberg \& Hill (1987), percent frequency of occurrence $(\% \mathrm{FOC})$ was used to quantify all food types. Because of the fragmented nature of the food items in the foreguts of the prawns only some food types could be accurately quantified and/or measured. In this study, the numbers of copepods and diatoms were counted and the length of filamentous algae was measured then converted into quantities per unit volume of foregut, where foregut volume $(\mu \mathrm{l})=0.0071 \mathrm{CL}^{2.8961}$ (Wassenberg \& Hill 1987). A Kruskal-Wallis test (Conover 1971) was used to test for diel differences in the overall range of diet items for each size class. Diel differences in the numbers of copepods and diatoms and length of filamentous algae were examined using ANOVA and SNK. Copepod carapaces and gastropod opercula were common food types which were usually intact in the prawns' foreguts. The width of each copepod carapace and the length (of the longest axis) of each gastropod operculum were measured to give information on the sizes of copepods and gastropods consumed by the different sizes of prawns.

Results and discussion. Thirty-six food types were recorded in the foreguts of juvenile Penaeus esculentus ranging from 2 to $18 \mathrm{~mm} \mathrm{CL}$. The most common food types were crustaceans (copepods, decapods and ostracods), molluscs (gastropods), diatoms, filamentous algae and seagrass (Table 1). No diel changes in the overall range of diet items were detected $(p>0.05$, Kruskal-Wallis test) so the data were pooled within size classes; however, both small and medium juveniles ate more filamentous algae at night (Fig. 1, $\mathrm{p}<0.05$, SNK, the data were $\log _{10}$ transformed). Although most of the food types identified in this study have been reported previously for $P$. esculentus in Toondah Harbour (Wassenberg \& Hill 1987, Wassenberg 1990) and for other Penaeus species (Dall et al. 1990), this study has demonstrated that the diet of $P$. esculentus juveniles changes with ontogeny with pronounced changes in their use of plant material.

Penaeus esculentus juveniles ate a more diverse range of food types as they grew. The smallest prawns (2 to $3 \mathrm{~mm} \mathrm{CL}$ ), which had recently settled out of the plankton, fed on 9 food types but they ate predominantly copepods (mainly harpacticoids and some calanoids, pers. obs.) and diatoms. Copepods and diatoms were probably the major food types captured from the 
Table 1. Penaeus esculentus. Percent frequency of occurrence (\%FOC) of food types found in the foreguts of small ( 2 to $5 \mathrm{~mm}$ carapace length, $\mathrm{CL}$ ), medium (9 to $12 \mathrm{~mm} \mathrm{CL}$ ) and large $(15$ to $18 \mathrm{~mm} \mathrm{CL}$ ) juveniles. Forty prawns were examined in each size class

\begin{tabular}{|c|c|c|c|}
\hline \multirow[t]{2}{*}{ Food item } & \multicolumn{3}{|c|}{$\begin{array}{c}\text { Frequency of occurrence (\%) } \\
\text { Size of prawn }\end{array}$} \\
\hline & Small & Medium & Large \\
\hline \multicolumn{4}{|l|}{ Animal } \\
\hline \multicolumn{4}{|l|}{ Annelida } \\
\hline \multicolumn{4}{|l|}{ Polychaeta } \\
\hline Family Nereidae & 0 & 27.5 & 55 \\
\hline Family Terebellidae & 0 & 5 & 7.5 \\
\hline Total & 0 & 32.5 & 62.5 \\
\hline \multicolumn{4}{|l|}{ Bryozoa } \\
\hline Unidentified type 1 & 2.5 & 25 & 37.5 \\
\hline Unidentified type 2 & 2.5 & 45 & 52.5 \\
\hline Total & 5 & 55 & 75 \\
\hline \multicolumn{4}{|l|}{ Chelicerata } \\
\hline Pycnogonida & 0 & 2.5 & 0 \\
\hline \multicolumn{4}{|l|}{ Ciliophora } \\
\hline Lorica spp. & 2.5 & 2.5 & 5 \\
\hline Unidentified & 2.5 & 2.5 & 0 \\
\hline \multicolumn{4}{|l|}{ Crustacea } \\
\hline Copepoda & 100 & 100 & 92.5 \\
\hline \multicolumn{4}{|l|}{ Ostracoda } \\
\hline Loxoconha cf. australis & 30 & 100 & 82.5 \\
\hline Unidentified type 1 & 0 & 12.5 & 45 \\
\hline Unidentified other & 45 & 62.5 & 62.5 \\
\hline Total & 55 & 100 & 92.5 \\
\hline \multicolumn{4}{|l|}{ Malacostraca } \\
\hline Amphipoda & 10 & 25 & 20 \\
\hline Decapoda & 25 & 87.5 & 97.5 \\
\hline Isopoda & 0 & 10 & 12.5 \\
\hline Tanaidaecea & 0 & 2.5 & 2.5 \\
\hline \multicolumn{4}{|l|}{ Mollusca } \\
\hline Bivalvia & 2.5 & 12.5 & 50 \\
\hline Gastropoda & 25 & 100 & 97.5 \\
\hline Nematoda & 0 & 15 & 27.5 \\
\hline Pisces & 2.5 & 2.5 & 7.5 \\
\hline \multicolumn{4}{|l|}{ Sarcodina } \\
\hline Foraminifera & 7.5 & 42.5 & 75 \\
\hline Sipuncula & 0 & 2.5 & 7.5 \\
\hline \multicolumn{4}{|l|}{ Unidentified } \\
\hline Eggs & 20 & 87.5 & 85 \\
\hline Egg case & 0 & 20 & 10 \\
\hline Animals (several types) & 35 & 42.5 & 37.5 \\
\hline \multicolumn{4}{|l|}{ Plant } \\
\hline Diatoms & 100 & 100 & 100 \\
\hline Filamentous algae & 52.5 & 87.5 & 77.5 \\
\hline \multicolumn{4}{|l|}{ Seagrass } \\
\hline Zostera capricorni & 0 & 55 & 85 \\
\hline Halophila ovalis & 0 & 0 & 2.5 \\
\hline
\end{tabular}

plankton before the prawns settled on the seagrass bed. At about $5 \mathrm{~mm} \mathrm{CL}$ (when the prawns were about 2 wk older), the prawns fed on 15 food types and, by about $9 \mathrm{~mm} \mathrm{CL}$, they were eating the full range of food recorded (up to 36 food types).

Small juveniles mostly ate smaller food types such as copepods and diatoms. The nutritional importance of

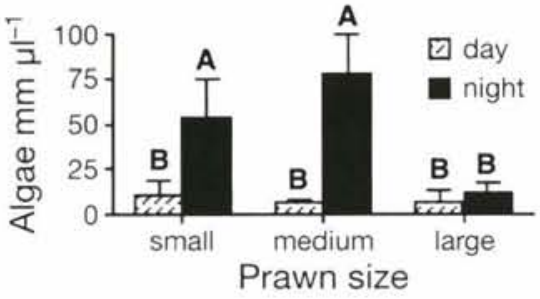

Fig. 1. Penaeus esculentus. Diel differences in the mean (+SE) length of filamentous algae ( $\mathrm{mm}$ per $\mu \mathrm{l}$ of foregut) eaten by small, medium and large juveniles. Different letters indicate significant differences $\left(\mathrm{p}<0.05, \mathrm{SNK}\right.$, the data were $\log _{10^{-}}$ transformed)

these small sized foods probably diminishes as the prawns grow and this is reflected in a proportional decrease in the amounts of copepods and diatoms in the foreguts of larger prawns. For example, small juveniles ate significantly more copepods (30.9 copepods $\mu \mathrm{l}^{-1}$ of foregut) than both medium (1.4) and large $(0.22)$ juveniles $\left(\mathrm{p}<0.05\right.$, SNK test, data was $\log _{10}$ transformed; Fig. 2); similarly, small juveniles ate more diatoms (1211 diatoms $\mu^{-1}$ of foregut) than medium (488) and large (254) juveniles ( $\mathrm{p}<0.05$, SNK, data were $\log _{10}$ transformed; Fig. 3a). The major changes in the use of some food types by different sized prawns can probably be attributed to an increase in the size and power of the feeding apparatus e.g. chelae and mouthparts. Larger juveniles ate prey which was more difficult to capture and eat, such as polychaetes which hold-fast in their burrows, fast-moving decapods and large thick-shelled gastropods and foraminiferans, e.g. decapod fragments were found in only $25 \%$ of the small juvenile foreguts examined whereas they were present in 87.5 and $97.5 \%$ of the foreguts of medium and large juveniles, respectively.

Interestingly, large juveniles were found to continue to eat small sized copepods and gastropods (Fig. 4). If the different sized prawns were competing for the same food type then the (more abundant) smaller sized prawns are most likely to be affected because their diets are less diverse than those of larger juveniles.

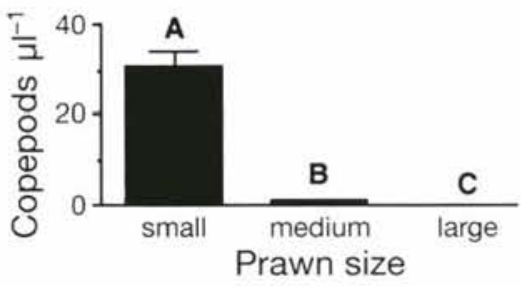

Fig. 2. Penaeus esculentus. Mean (+ SE) number of copepods per $\mu l$ of foregut eaten by small, medium and large juveniles. Different letters indicate significant differences $(\mathrm{p}<0.05$, SNK, the data were $\log _{10}$-transformed) 
(a) Diatoms $\mu \mathrm{l}^{-1}$

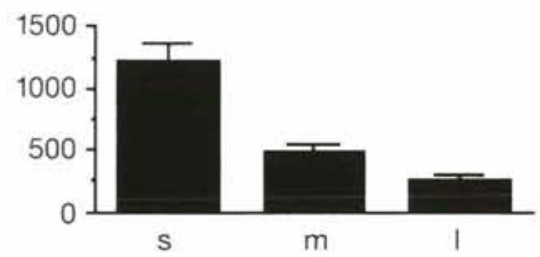

(b) Algae ${\mathrm{mm} \mu \mathrm{l}^{-1}}^{-1}$

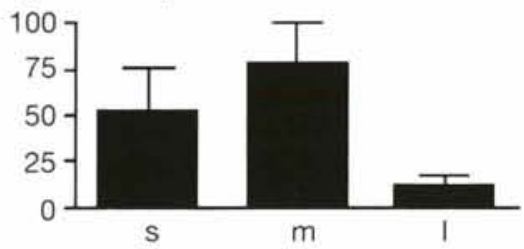

(c) Seagrass (\% FOC)

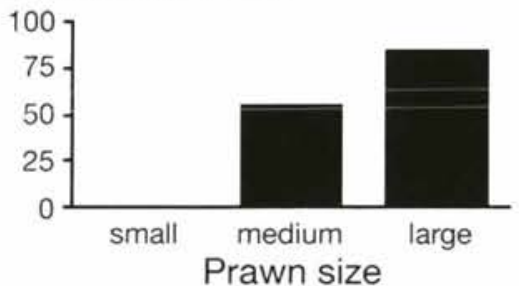

Fig. 3. Penaeus esculentus. Types of plant material eaten by small, medium and large juveniles. Mean (+ SE) number of diatoms and length of filamentous algae are quantities per $\mu \mathrm{l}$ of foregut. Length of filamentous algae was determined from prawns collected at night only. Seagrass is percent frequency of occurrence $(\% \mathrm{FOC})$

(a) Operculum length $(\mathrm{mm})$

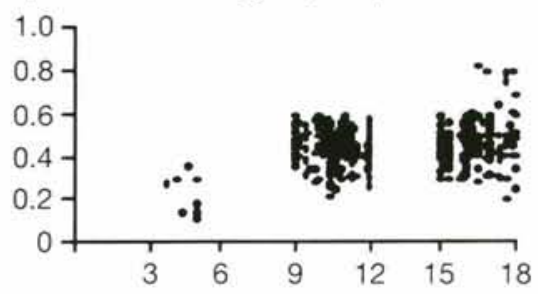

(b) Copepod width ( $\mathrm{mm}$ )

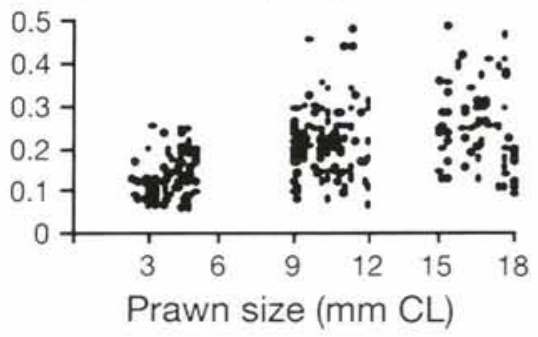

Fig. 4. Penaeus esculentus. Relationship between prawn size (carapace length $\mathrm{mm}$ ) and (a) the operculum length ( $\mathrm{mm}$ ) of gastropods and (b) the carapace width (mm) of copepods, found in the foreguts of juveniles
However, there is little evidence in the literature to suggest that these food types are ever limited in seagrass beds.

Diatoms were found in the foreguts of all prawns $(100 \% \mathrm{FOC})$. Twenty-eight genera of diatoms were identified and a common range of diatom types was eaten by all sizes of juvenile (Table 2). However, as the importance of diatoms appears to decrease with increasing prawn size, it is likely that many of the diatoms found in the foreguts of the older prawns were epiphytes and were inadvertently ingested with filamentous algae and seagrass.

Fast-growing, filamentous algae are generally abundant on seagrass shoots and have been found in the foreguts of juveniles of several Penaeus species (Dall et al. 1990). In this study, all sizes of Penaeus esculentus juvenile were found to have eaten filamentous algae, but medium and small juveniles consumed the largest amounts, mainly at night: 78,53 and $12.4 \mathrm{~mm} \mathrm{Hl}^{-1}$ foregut for medium, small and large juveniles, respectively $\left(\mathrm{p}<0.05, \mathrm{SNK}\right.$, data were $\log _{10}$ transformed; Fig. 3b). More filamentous algae was consumed by small and medium sized juveniles at night (Fig. 2) because they were probably less successful at catching active prey types in the dark. One $11.3 \mathrm{~mm} \mathrm{CL}$ prawn was found to contain about $2.2 \mathrm{~m}$ of Polysiphonia spp.

Table 2. Penaeus esculentus. Percent frequency of occurrence (\%FOC) of common ( $>40 \% \mathrm{FOC}$ ) diatoms found in the foreguts of small ( 2 to $5 \mathrm{~mm}$ carapace length, CL), medium ( 9 to $12 \mathrm{~mm} \mathrm{CL}$ ) and large (15 to $18 \mathrm{~mm} \mathrm{CL}$ ) juveniles. Forty prawns were examined in each size class

\begin{tabular}{|c|c|c|c|}
\hline \multirow[t]{2}{*}{ Genus (species) } & \multicolumn{3}{|c|}{$\begin{array}{c}\text { Frequency of occurrence }(\%) \\
\text { Size of prawn }\end{array}$} \\
\hline & Small & $\begin{array}{l}\text { Size of prawn } \\
\text { Medium }\end{array}$ & Large \\
\hline Achnanthes type 1 & 90 & 95 & 95 \\
\hline Navicula cf. ramosissma & 82.5 & 92.5 & 90 \\
\hline Pleurosigma & 77.5 & 60 & 67.5 \\
\hline Mastogloia & 75 & 80 & 85 \\
\hline Cocconeis cf. scutellum & 62.5 & 75 & 87.5 \\
\hline Rhopalodia & 60 & 67.5 & 57.5 \\
\hline Nitzschia & 60 & 70 & 72.5 \\
\hline Thalassiothrix & 57.5 & 87.5 & 95 \\
\hline Navicula type 2 & 55 & 82.5 & 85 \\
\hline Grammatophora & 55 & 75 & 70 \\
\hline cf. Thalassiothrix type 2 & 52.5 & 72.5 & 60 \\
\hline Biddulphia/Odontella & 45 & 60 & 85 \\
\hline Synedra & 42.5 & 45 & 55 \\
\hline Amphora & 40 & 47.5 & 47.5 \\
\hline Coscinodiscus & 30 & 70 & 62.5 \\
\hline Diploneis cf. ovalis & 25 & 70 & 52.5 \\
\hline Grammatophora cf. oceanica & 22.5 & 65 & 65 \\
\hline Pinnularia & 17.5 & 52.5 & 47.5 \\
\hline Cocconeis type 2 & 22.5 & 50 & 52.5 \\
\hline Nitzschia cf. sigma & 27.5 & 42.5 & 45 \\
\hline Rhabdonema & 22.5 & 32.5 & 57.5 \\
\hline
\end{tabular}


Several species of decapod have been reported to eat seagrass, despite the presence of noxious sulphated phenolic compounds (Joll \& Phillips 1984, Edgar 1990), but relatively few studies have reported seagrass in the diets of penaeid prawns (e.g. Mohanty 1975, Wassenberg 1990). In this study, seagrass material could not be quantified because it was often too shredded and/or folded; however, $55 \%$ of medium sized Penaeus esculentus juveniles and $85 \%$ of large juveniles were found to have eaten some part of a Zostera capricorni plant (Table 1, Fig. 3c). Furthermore, in addition to seeds (first reported by Wassenberg \& Hill 1987), leaf, ligule material, roots and rhizomes were also consumed.

Stable carbon isotope studies on Penaeus prawns in seagrass beds indicate that seagrass leaf is probably not assimilated (Kitting et al. 1984). This suggests that seagrass may be eaten for the epiphytes (e.g. diatoms, filamentous algae and bryozoans) attached to it. However, depending on the season, most parts of a seagrass plant contain nutritious substances. Seeds contain starch granules which consist of up to $60 \%$ digestible carbohydrate (Dall et al. 1992); rhizomes also contain starch granules and presumably their composition is similar to that of the starch granules found in the seeds. Roots, rhizomes and leaves can be rich in soluble sugars, especially sucrose which has been found to be important in the growth of prawns (Dall et al. 1990). Seagrass leaves also contain large quantities of structural celluloses which have been reported to stimulate growth (Venkataramiah et al. 1975, Fair et al. 1980).

Because Penaeus esculentus is a selective feeder, Wassenberg (1990) suggested that Zostera seeds (which contain starch granules) are an important seasonal food for juveniles (seeds are present from November to March in Toondah Harbour). Results from this study are consistent with this because starch granules were being eaten when no shortage of other food types was apparent; furthermore, the starch granules were from both seeds and rhizomes, and in the latter they are available all-year round. On the other hand, Wigand \& Churchill (1988) concluded that Zostera seeds were only an alternative for fish and crustaceans, when other food types were unavailable. Dall et al. (1992) have suggested that the main nutritional benefit is the high energy content of the seeds.

The types of plants eaten by Penaeus esculentus juveniles appear to change progressively from diatoms to filamentous algae to seagrass as the prawns grow (Fig. 3). Eating plant material has some advantages e.g. plants require little energy to be captured and their abundance does not change rapidly. Further- more, some plant types eaten by $P$. esculentus have energy contents similar to that of animal food (Table 3 ). Because $P$. esculentus is a selective feeder, the use of plant material is probably due to nutritional requirements; however, more research is required to identify the beneficial components of plants. This is particularly important for the development of diets for aquaculture.

It is well documented that Penaeus esculentus juveniles settle predominantly in seagrass and that these areas provide protection and food. The complex use of seagrass and its epiphytic filamentous algae and diatoms in the diet provides a clearer understanding of the dependence between $P$. esculentus juveniles and their preferred habitat.

Acknowledgements. This work formed part of a Ph.D. at the University of New South Wales. Support was received from an Australian Postgraduate Research Award. Thanks to CSIRO, Division of Fisheries, Cleveland for the use of equipment and facilities. Drs D. Milton and N. Preston (CSIRO) gave constructive criticism of drafts of this manuscript.

\section{LITERATURE CITED}

Conover, W. J. (1971). Practical nonparametric statistics. John Wiley \& Sons, New York

Dall, W., Hill, B. J., Rothlisberg, P. C., Staples, D. J. (1990). The biology of the Penaeidae. In: Blaxter, J. H. S., Southward, A. J. (eds.) Advances in marine biology, Vol. 27. Academic Press, London, p. 1-489

Dall, W., Smith, D. M., Moore, L. E. (1992). The composition of Zostera capricorni seeds: a seasonal natural food of juvenile Penaeus esculentus Haswell (Penaeidae: Decapoda). Aquaculture 101: 75-83

Edgar, G. J. (1990). Predator-prey interactions in seagrass bed. II Distribution and diet of the blue manna crab Portunus pelgicus Linnaeus at Cliff Head, Western Australia. J. exp. mar. Biol. Ecol. 139: 23-32 
Fair, P. H., Fortner, A. R., Millikin, M. R., Sick, L. V. (1980). Effects of dietary fibre on growth, assimilation and cellulase activity of the prawn (Macrobrachium rosenbergii). Proc. WId Aquacult. Soc. 11: 369-381

Joll, L. M., Phillips, B. F. (1984). Natural diet and growth of juvenile western rock lobsters Panulirus cygnus George. J. exp. mar. Biol. Ecol. 75: 145-169

Kitting, C. L., Fry, B., Morgan, M. D. (1984). Detection of conspicuous epiphytic algae supporting food webs in seagrass meadows. Oecologia 62: 145-149

Laprise, R., Blaber, S. J. M. (1992). Predation by Moses perch, Lutjanus russelli, and blue-spotted trevally, Caranx bucculentus, on juvenile brown tiger prawn, Penaeus esculentus: effects of habitat structure and time of day. J. Fish Biol. 40: 627-635

McRoy, C. P. (1970). Standing stocks and other features of eelgrass (Zostera marina) populations on the coast of Alaska. J. Fish. Res. Bd Can. 27: 1811-1821

Mohanty, S. K. (1975). On the food of 'Bagda', Penaeus monodon Fabricus from the Chilka Lake. Bull. Dep. mar. Sci. Univ. Cochin. 3: 645-652

O'Brien, C. J. (1992). Some aspects of the production ecology of Penaeus esculentus Haswell (Decapoda: Penaeidae) juveniles. Ph.D. thesis, University of New South Wales

Olson, F. C. W. (1950). Quantitative estimates of filamentous algae. Trans. Am. Microsc. Soc. 69: 272-279

Paine, R. T., Vadas, R. L. (1969). Calorific values of benthic marine algae and their postulated relation to invertebrate food preference. Mar. Biol. 4: 79-86

Ricard, M. (1987). Diatomophycées. In: Sournia, A. (ed.) Atlas du Phytoplankton Marin, Vol. II. Editions du Centre National de la Recherche Scientifique, Paris, p. 1-297

This note was submitted to the editor
Romer, G. S., McLachlan, A. (1986). Mullet grazing on surf diatom accumulations. J. Fish Biol. 28: 93-104

Round, F. E., Crawford, R. M., Mann, D. G. (1992). The diatoms: biology and morphology of the genera. Cambridge University Press, Cambridge

Slobodkin, L. B., Richman, S. (1961). Calories gm. in species of animals. Nature 191: 299

Stoner, A. W., Zimmerman, R. J. (1988). Food pathways associated with penaeid shrimps in a mangrove fringed estuary. Fish. Bull. U.S. 86: 543-551

Thayer, G. W., Schaaf, W. E., Angelovic, J. W., Lacroix, M. W. (1973). Caloric measurements of some estuarine organisms. Fish. Bull. U.S. 71: 289-296

Thomas, D. P. (1978). The ecology of diatom epiphytes of Zostera sp. in the Onkaparinga Estuary, South Australia (1974-1977). Ph.D. thesis, University of Adelaide

Throndsen, J. (1981). Preservation and storage. In: Sournia, A. (ed.) 'Phytoplankton manual'. UNESCO. Monographs on Oceanographic Methodology 6: 69-74

Venkataramiah, A., Lakshmi, G. J., Gunter, G. (1975). Effect of protein level and vegetable matter on growth and food conversion efficiency of brown shrimp. Aquaculture 6: $115-125$

Wassenberg, T. J. (1990). Seasonal feeding on Zostera capricorni seeds by juvenile Penaeus esculentus (Crustacea: Decapoda) in Moreton Bay, Queensland. Aust. J. mar. Freshwat. Res. 41: 301-310

Wassenberg, T. J., Hill, B. J. (1987). Natural diet of the tiger prawns Penaeus esculentus and P. semisulcatus. Aust. J. mar. Freshwat. Res. 38: 169-182

Wigand, C., Churchill, A. C. (1988). Laboratory studies on eelgrass seed and seedling predation. Estuaries 11: 180-183

Manuscript first received: March 14, 1994

Revised version accepted: June 2, 1994 